\title{
Probabilistic risk assessment of diuron and prometryn in the Gwydir River catchment, Australia, with the input of a novel bioassay based on algal growth
}

\author{
Yajuan Shi ${ }^{\text {a,* }}$, Mitchell Burns ${ }^{\text {b,c }}$, Raymond J. Ritchie ${ }^{c}$, Angus Crossan ${ }^{\text {b }}$, Ivan R. Kennedy ${ }^{\text {b }}$ \\ a State Key Laboratory of Urban and Regional Ecology, Research Center for Eco-Environmental Sciences, Chinese Academy of Sciences, Beijing 100085, China \\ ${ }^{\mathrm{b}}$ Faculty of Agriculture and Environment, University of Sydney, NSW 2000, Australia

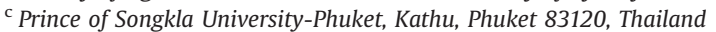

\section{A R T I C L E I N F O}

\section{Article history:}

Received 19 October 2013

Received in revised form

8 April 2014

Accepted 20 April 2014

Available online 20 May 2014

Keywords:

Toxicity bioassay

Eco-toxicity

Database study

Probabilistic risk assessment

\begin{abstract}
A B S T R A C T
A probabilistic risk assessment of the selected herbicides (diuron and prometryn) in the Gwydir River catchment was conducted, with the input of the $\mathrm{EC}_{50}$ values derived from both literature and a novel bioassay. Laboratory test based on growth of algae exposed to herbicides assayed with a microplate reader was used to examine the toxicity of diuron and prometryn on the growth of Chlorella vulgaris. Both herbicides showed concentration dependent toxicity in inhibiting the growth of Chlorella during the exposure period of 18-72 h. Diuron caused more toxicity as judged by growth rates than prometryn. Thalaba Creek at Merrywinebone was identified as the 'hotspot' for diuron and prometryn risk in the Gwydir catchment. The use of microplate assays coupled with probabilistic risk assessment is recommended for rapid assessment of ecotoxicity of indigenous species, allowing identification of locations in river catchments requiring environmental management.
\end{abstract}

(c) 2014 Elsevier Inc. All rights reserved.

\section{Introduction}

Herbicides are the most widely used of chemical pesticides for agricultural production and landscape management. For example in the U.S., herbicides account for about 70 percent of all pesticides used (Kellogg et al., 2002). The environmental risk of herbicides should be evaluated near sites of use, even though basic ecotoxicological tests have been conducted before they can be registered for marketing. For example, diuron and prometryn, which are both used globally are photosynthetic PSII herbicides that are considered only slightly or moderately toxic to mammals and humans; however concerns have arisen because they are members of a class claimed to be carcinogenic, or may affect the development as reproductive toxins (Orton et al., 2009; Kegley et al., 2010). For this reason, more reliable evidence is needed to test these claims and investigate their ecological effects.

The Gwydir River catchment is an agriculturally and ecologically important catchment located in northern New South Wales, Australia. The land use in the catchment is predominantly agricultural production, with grazing being the dominant practice and a variety of cropping practices with cereal and irrigated cotton being the dominant types. The Gwydir wetlands, an area of ecological significance in

\footnotetext{
* Corresponding author. Fax: +86 1062918177

E-mail address: yajuanshi@rcees.ac.cn (Y. Shi).
}

Gwydir catchment, supports many migratory and native bird species, as well as many other fresh water organisms, including crustaceans, native and exotic fish species. The aquatic ecosystem may be in danger from runoff contaminated with herbicides such as diuron and prometryn, which are used in the watershed. A suitable way was needed to assess the risk of the herbicides in this catchment.

Probabilistic risk assessment (PRA) allows more quantitative evaluation of the overall risk of polluting chemicals to ecosystems rather than relying on data for single species (Solomon et al., 2000), preferably given the availability of toxicity data on local biota. Fast and accurate methods for evaluating the toxicity and estimating risk are urgently needed to obtain the necessary data for effective PRA.

A number of bioassays have been reported for the assessment of chemical toxins on aquatic ecosystems; inter alia, these include bacterial tests, fish, coral, algae and water flea tests et al. (Jones et al. 2003; Huang et al. 2005; Relyea 2009). Microalgae are considered to be sensitive indicators of various toxicants (Bengtson-Nash et al., 2005; Ma et al., 2006) because they are frequently found in aquatic environments, and are a vital component for primary production, responding rapidly to environmental changes due to their unicellular structure and short generation times.

The standard bioassays of algae, i.e. ISO 8962 (1989) and the OECD 201 (1984), are proven methods for evaluating the toxicity of chemicals. However, the experimental formats are labor intensive, specifying large sample volumes, requiring large areas of benchspace, 
and generating large volumes of waste. Since the 1990s, many researchers have attempted to optimize the procedure, performing tests at microscale using cuvettes, scintillation tubes, or microplates (Arensberg et al., 1995; Nguyen-Ngoc et al., 2009; Paixao et al., 2008; Rojiekova et al., 1998). The 24- or 96-well algal growth inhibition assay performed in a microplate, gave comparable results to standard flask bioassay for the tested algae (Thellen et al., 1990; Rojiekova et al., 1998; Eisentraeger et al., 2003; Horvatic et al., 2007; Riedl and Altenburger, 2007). This simpler method has been used in routine toxicity testing, pollutant phytotoxicity screening, and screening of sensitivity of algae. In terms of pollutants, many heavy metals, and organic pollutants, have been tested with these micro-scale methods, however literature reports of assessments for the herbicides diuron and prometryn are rare (Gomez De Barreda Ferraz et al., 2004; Gregor and Maralek, 2005; Paixao et al., 2008).

In this paper, a bioassay based on growth of algae exposed to herbicides assayed with a 96-well microplate reader was used to examine the effect of diuron and prometryn on the growth of Chlorella. These experimental data were further supplemented by undertaking a risk assessment of diuron and prometryn in the Gwydir River catchment using the $\mathrm{EC}_{50}$ values generated from the laboratory test and the US EPA ECOTOX database, in order to develop and validate a novel bioassay on evaluating the toxicity of herbicides on algae and to investigate the potential effectiveness of applying PRA of diuron and prometryn in the Gwydir River catchment of northern New South Wales. This information will have potential value for risk management of pesticides used in this catchment.

\section{Materials and methods}

\subsection{Algal cultures}

Chlorella vulgaris was obtained from School of Biological Sciences, University of Sydney and grown in MBL medium (Nicholls, 1973). Cultures were grown in a semicontinuous manner in $500 \mathrm{~mL}$ Erlenmeyer flasks, where $100 \mathrm{~mL}$ of the total $200 \mathrm{~mL}$ culture was discarded daily and $100 \mathrm{~mL}$ of fresh medium was added to the culture. Cultures were kept on an orbital shaker at $120 \mathrm{rpm}$ and $25{ }^{\circ} \mathrm{C}$ and under continuous white lights at about $50 \mu \mathrm{mol}$ of quanta $(400-700 \mathrm{~nm}) \mathrm{m}^{-2} \mathrm{~s}^{-1}$.

\subsection{Chemicals and reagents}

Diuron (99.7 percent pure) and prometryn (purity 97 percent) were obtained from Sigma-Aldrich Chemical Company, Castle Hill, Australia. All chemicals used in the media preparation were laboratory reagent standard. The chemical properties of the tested chemicals relevant to their toxicity are shown in appendices Table A.

\subsection{Microplate bioassay}

The microplate bioassays were performed according to Rojiekova et al. (1998), Eisentraeger et al. (2003) and Paixao et al. (2008) with a modification. The algae were exposed to various dose of diuron (at nominal concentrations $0.125,0.25,0.5$, $5,10,50 \mu \mathrm{g} \mathrm{L}^{-1}$ ) and prometryn (at nominal concentrations $0.5,5,10,25,50$, $100 \mu \mathrm{g} \mathrm{L}^{-1}$ ) for $72 \mathrm{~h}$. Growth of cultures was measured at $540 \mathrm{~nm}$ wavelength using a microplate reader (Multiskan Ascent model 353 from Labsystems, Helsinki) twice a day.

Test cultures containing the desired concentrations of diuron and prometryn and the desired quantity of algal inocula were prepared by dilution with sterile algal medium aliquot of stock solutions of herbicides and algal suspensions. The inocula were obtained from a pre-culture which was incubated semi-continuously under test conditions and used when cells were growing exponentially.

Growth inhibition tests of herbicides were performed in 96-well, sterilized polystyrene microplates, with lids and flat bottoms. The final test volume was $150 \mu \mathrm{L}$ per well. The microplate bioassays were conducted with twelve replicates of each test concentrations of pesticides, and controls (culture medium and algae).

The microplates were placed on an orbital shaker oscillating at $120 \mathrm{rpm}$ and $25{ }^{\circ} \mathrm{C}$, under continuous white fluorescent lights $\left(\sim 50 \mu \mathrm{mol} \mathrm{m}{ }^{-2} \mathrm{~s}^{-1}\right)$. The exact location under the light bank was randomly alternated after each absorbance reading. The microplates were automatically shaken for $10 \mathrm{~s}$ at $960 \mathrm{rpm}$ before each reading.
Plots of growth curves were graphed and inspected visually to collect data on variations in growth pattern in addition to calculating apparent exponential doubling times. Growth rates for $72 \mathrm{~h}$ were calculated and then the percent inhibition for each treatment replicate was determined. ANOVA and Student Newman-Keuls multiple range test was used to determine if treatments were significantly different from each other. Results were deemed significantly different at the probability level $P$ less than 0.05 . $\mathrm{EC}_{50}(0-72 \mathrm{~h})$ values with standard deviation were estimated by the linear regression of probit of percentage growth on $\log _{10}$ of the concentration of herbicides. All statistical analyses were performed using the software packages SPSS.

\subsection{Risk assessment}

To provide a context to predict ecological effects in the field, probabilistic risk assessment (PRA) comparing distributions of actual exposure concentrations in surface waters and published species sensitivity data from laboratory toxicity studies including our results was used to define the relationship between measures of effects and assessment end points.

Diuron and prometryn exposure data from 12 monitoring sites were collected from the Gwydir River catchment of northern New South Wales, Australia by the NSW Department of Water and Energy for the period 1991-2007. Sampling was conducted monthly independently of chemical use, but with two or three samples per month collected for months that were perceived to be riskier because of higher rainfall and during the cotton crop growing season.

Species sensitivity distributions (SSDs) for each herbicide were constructed with $\mathrm{LC}_{50}$ and $\mathrm{EC}_{50}$ values to determine the sensitivity of aquatic animals, plants and algae. Toxicity data employed in the SSDs were developed from toxicity data gathered from the US EPA ECOTOX database (http://www.epa.gov/ecotox), and the results of the laboratory test mentioned above. The measurement endpoints considered all laboratory toxicity data related to growth. 163 records for $\mathrm{EC}_{50}$ or $\mathrm{LC}_{50}$ of diuron and 51 records of prometryn were selected. Where more than one toxicity value was available for a single species, the geometric mean was calculated to favor the more sensitive studies (Maltby et al., 2005; Rand et al., 2010). Toxicity data for 60 species by diuron and 35 species by prometryn were finally derived to construct the SSD for the two herbicides.

The potential risk of the herbicides in the Gwydir catchment freshwaters were examined by integrating the probability distributions of the exposure concentrations by sites with the SSDs of each herbicide. Distributions of exposure and species sensitivity were constructed by the methods of USEPA (1998), Solomon et al. (2000), and Maltby et al. (2005). The degree of overlap between the exposure distributions and the SSDs was used to estimate the number of species affected given a percentage of the time (Solomon et al., 1996). Where the exposure and species sensitivity distributions overlap at the five percent species sensitivity threshold denotes risk. The probability that the five percent effect threshold (based on Australia standard regulatory approach) can be exceeded at any time can then be determined. When the calculation of risk was completed, the output was applied to Geographical Information Systems software (ArcGIS) allowing for the identification of hotspots for exposure in the catchment.

\section{Results}

\subsection{Microplate bioassays}

Plots of growth curves of diuron and prometryn (Fig. 1a and b) showed that the algae displayed exponential growth during the test period. Importantly, both diuron and prometryn showed toxicity in terms of both herbicide concentration and time dependent toxicity in inhibiting the growth of Chlorella during the exposure period of $18-72 \mathrm{~h}$ (Two-way ANOVA analysis, $P=0.000$ for both the variables of time and herbicides concentrations). Post hoc tests showed that significant inhibition of growth started on the 21st hour, and the inhibition increased significantly at the end of day -2 and day-3 $(P<0.05)$.

The average growth rates of algae at $0-72 \mathrm{~h}$ for diuron are shown in Fig. 2(a). The concentration of diuron that caused significant effects $(P<0.05)$ on the algal growth with respect to control values ranged from $0.125 \mu \mathrm{g} \mathrm{L}^{-1}$ to $50 \mu \mathrm{g} \mathrm{L}^{-1}$. Reduction in growth rates was observed with an increase of diuron concentrations. The growth inhibition of algae treated with $25 \mu \mathrm{g} \mathrm{L}^{-1}$ and $50 \mu \mathrm{g} \mathrm{L}^{-1}$ of diuron were 36.9 percent and 56.2 percent respectively. The $\mathrm{EC}_{50}$ for the growth rates inhibition was calculated as $45 \pm 5 \mu \mathrm{g} \mathrm{L}^{-1}$ (Pearsons $R=0.989$ ). 
a

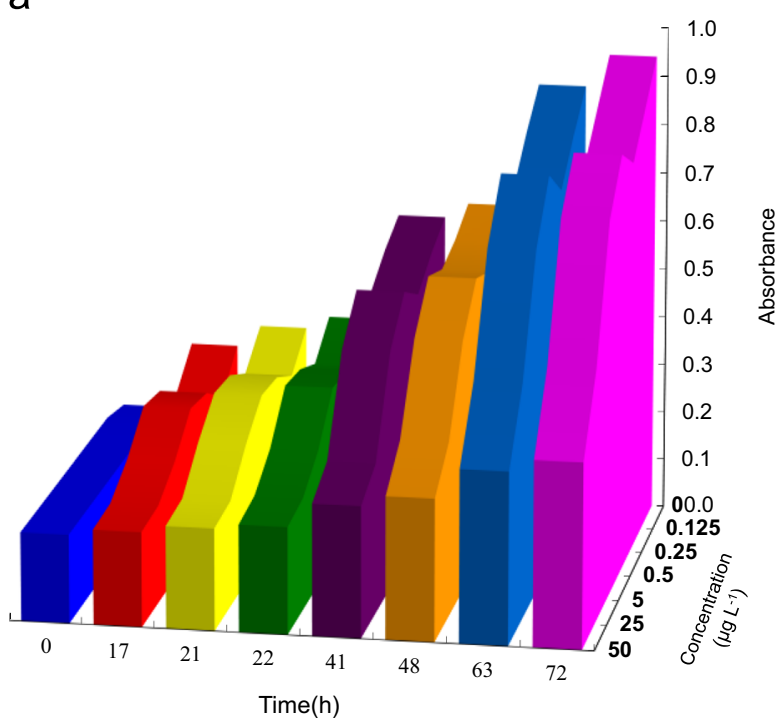

b

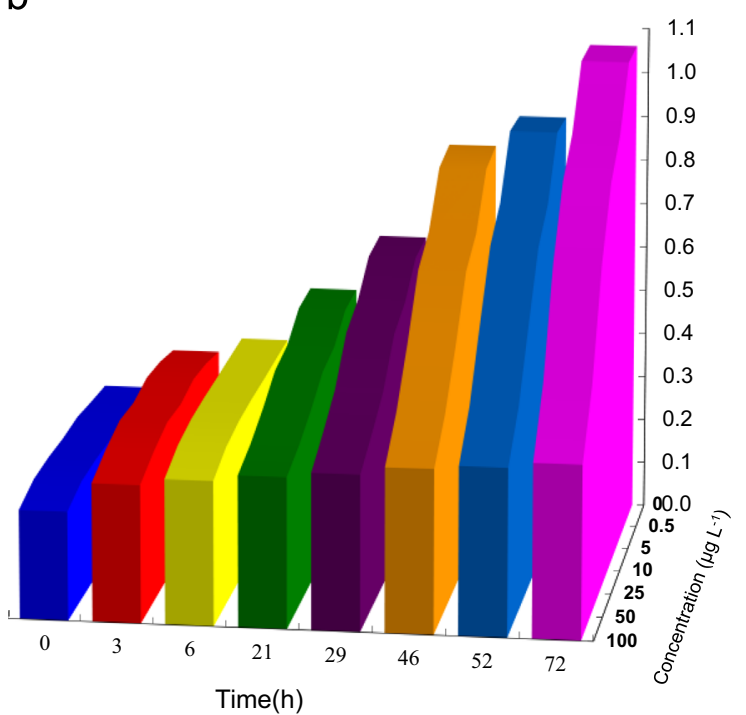

Fig. 1. Growth of Chlorella exposed to diuron and prometryn. (a) diuron and (b) prometryn.

Prometryn also showed concentration-dependent toxicity in inhibiting the growth of Chlorella (Fig. 2b). No significant inhibitory effect was observed for the treatment of $0.5 \mu \mathrm{g} \mathrm{L}^{-1}(P>0.05)$, all the other treatments with the concentration higher than $5 \mu \mathrm{g} \mathrm{L}^{-1}$ significantly inhibit the growth of Chlorella $(P<0.05)$. $\mathrm{EC}_{50}$ for the growth rates inhibition was calculated as $57 \pm 5 \mu \mathrm{g} \mathrm{L}^{-1}$ (Pearsons $R=0.994)$.

\subsection{Probability risk assessment}

\subsubsection{Exposure assessment}

The exposure assessment is designed to examine the co-occurrence of the stressors in surface water with the ecological receptors in question. A summary of the exposure data, distribution regression parameters and the corresponding 95 percent values estimated by the regression of the exposure distribution for each herbicide in each of the twelve site are presented in Tables 1 and 2. In four sites, diuron was detected frequently with detection rates ranging from twelve percent to 18.2 percent, in other three sites, the detection rates were around five percent. The 95th centile a
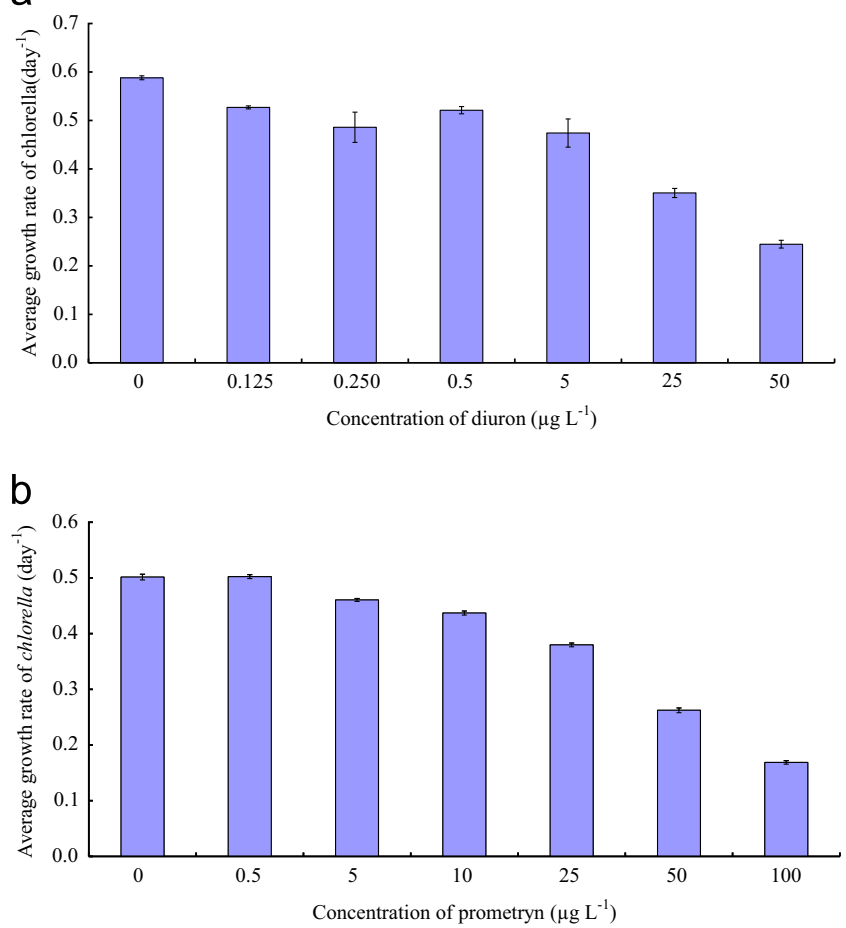

Fig. 2. The average growth rate of Chlorella at $0-72 \mathrm{~h}$ exposed to diuron and prometryn. (a) diuron and (b) prometryn.

values for diuron ranged between n.a and $1.5 \mu \mathrm{g} \mathrm{L}^{-1}$, the highest exposure appeared in Thalaba Creek at Merrywinebone.

Prometryn was detected infrequently. As a result, the 95th centile values for prometryn detection were much lower than for diuron, the peak value $1.8 \mu \mathrm{g} \mathrm{L}^{-1}$ appearing at the Thalaba Creek at Merrywinebone site, where diuron was also most frequently detected.

\subsubsection{Effects assessment}

Cumulative frequencies of logarithmic $\mathrm{LC}_{50}$ or $\mathrm{EC}_{50}$ values of aquatic animals, plants and algae were collected to produce the effects concentration distributions. The species rank was determined by ranking the log of the toxicity values. The species sensitivity distributions (SSDs) for diuron and prometryn are plotted in Fig. 3.

The SSDs were converted to straight line transformation of probability functions by probit transformation. By linear regression, the probit of diuron $=0.594 \mathrm{Lg}\left(\mathrm{LC}_{50} / \mathrm{EC}_{50}\right)+3.450, r^{2}=0.9449$, the probit of prometryn $=0.661 \mathrm{Lg}\left(\mathrm{LC}_{50} / \mathrm{EC}_{50}\right)+3.420, r^{2}=0.9303$.

The 5th centile concentration of effects from the cumulative frequency distribution of diuron and prometryn were $0.7 \mu \mathrm{g} \mathrm{L}^{-1}$ for diuron, and $0.8 \mu \mathrm{g} \mathrm{L}^{-1}$ for prometryn. Growth was more inhibited by diuron than prometryn.

\subsubsection{Risk characterization}

Joint probability curve method which integrated the exposure and effects distributions in the common axis was used to determine the likelihood of adverse ecological effects. The specific assessment end point was the protection of at least 95 percent of aquatic species. The probability that the five percent effect threshold was exceeded at any time can then be determined.

Examples of joint probability curves for diuron and prometryn at the selected monitoring sites in Gwydir catchment are shown in Appendices Figs. A and B, respectively. The probability that five percent of aquatic species will be in danger due to exposure to diuron in three sites (Gwydir River at Allambie Bridge, Carole 
Table 1

Exposure character, probit distribution regression parameters, 95th centile and probability that 95 percent of species be protected due to diuron in Gwydir catchment.

\begin{tabular}{|c|c|c|c|c|c|c|c|c|}
\hline \multirow[t]{2}{*}{ Location } & \multirow[t]{2}{*}{$\begin{array}{l}\text { No. of } \\
\text { samples }\end{array}$} & \multicolumn{2}{|c|}{$\begin{array}{l}\text { Exposure } \\
\text { concentration of } \\
\text { diuron }\left(\mu \mathrm{g} \mathrm{L}^{-1}\right)\end{array}$} & \multicolumn{3}{|c|}{$\begin{array}{l}\text { Distribution regression } \\
\text { parameters (probit } \\
\text { diruon }=m \operatorname{Lg} \text { conc }+b \text { ) }\end{array}$} & \multirow[t]{2}{*}{$\begin{array}{l}\text { 95th centile } \\
\left(\mu \mathrm{g} \mathrm{L}^{-1}\right)\end{array}$} & \multirow[t]{2}{*}{$\begin{array}{l}\text { Probability that } 95 \% \text { of } \\
\text { species be protected }(\%)\end{array}$} \\
\hline & & Max & Min & $m$ & $b$ & $r^{2}$ & & \\
\hline Mehi River at Moree & 79 & n.d & n.d & n.a & n.a & n.a & n.a & 0 \\
\hline Gwydir River at Yarraman Bridge & 79 & n.d & n.d & n.a & n.a & n.a & n.a & 0 \\
\hline Gwydir River at Gravesend & 169 & n.d & n.d & n.a & n.a & n.a & n.a & 0 \\
\hline Horton River at Rider (Killara) & 75 & n.d & n.d & n.a & n.a & n.a & n.a & 0 \\
\hline Warialda Creek at Warialda No 3 & 79 & n.d & n.d & n.a & n.a & n.a & n.a & 0 \\
\hline Gwydir River at Brageen Crossing & 230 & 0.6 & n.d & 1.19 & 7.87 & 0.92 & 0.1 & 0.36 \\
\hline Moomin Creek at Iffley & 202 & 2.3 & n.d & 0.61 & 7.36 & 0.95 & 0.1 & 1.18 \\
\hline Mehi River at Bronte & 229 & 36.5 & n.d & 0.41 & 7.07 & 0.93 & 0.1 & 2.24 \\
\hline Moomin Creek at Glendello & 72 & 2.9 & n.d & 0.72 & 7.01 & 0.89 & 0.3 & 2.92 \\
\hline Gwydir River at Alambie Bridge & 77 & 5.0 & n.d & 0.77 & 6.81 & 0.97 & 0.6 & 4.65 \\
\hline Carole Creek near Garah & 75 & 12.5 & n.d & 0.51 & 6.72 & 0.96 & 0.7 & 5.01 \\
\hline Thalaba Creek at Merrywinebone & 225 & 19.5 & n.d & 0.58 & 6.55 & 0.98 & 1.5 & 7.27 \\
\hline
\end{tabular}

Note: n.d signifies measurements determined to be less than the limit of quantitation.

n.a Signifies not applicability of linear regression to the dataset.

Table 2

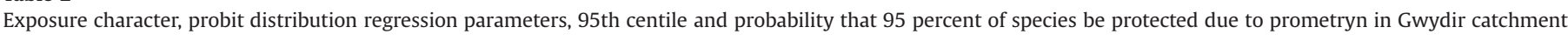

\begin{tabular}{|c|c|c|c|c|c|c|c|c|}
\hline \multirow[t]{2}{*}{ Location } & \multirow[t]{2}{*}{$\begin{array}{l}\text { No. of } \\
\text { samples }\end{array}$} & \multicolumn{2}{|c|}{$\begin{array}{l}\text { Exposure } \\
\text { concentration of } \\
\text { prometryn }\left(\mu \mathrm{g} \mathrm{L}^{-1}\right)\end{array}$} & \multicolumn{3}{|c|}{$\begin{array}{l}\text { Distribution regression } \\
\text { parameters (Probit } \\
\text { prometryn }=m \operatorname{Lg} \text { conc }+b \text { ) }\end{array}$} & \multirow[t]{2}{*}{$\begin{array}{l}\text { 95th centile } \\
\left(\mu \mathrm{g} \mathrm{L}^{-1}\right)\end{array}$} & \multirow[t]{2}{*}{$\begin{array}{l}\text { Probability that } 95 \% \text { of } \\
\text { species be protected (\%) }\end{array}$} \\
\hline & & Max & Min & $m$ & $b$ & $r^{2}$ & & \\
\hline Mehi River at Moree & 79 & n.d & n.d & n.a & n.a & n.a & n.a & 0 \\
\hline Gwydir River at Yarraman Bridge & 79 & n.d & n.d & n.a & n.a & n.a & n.a & 0 \\
\hline Gwydir River at Gravesend & 90 & n.d & n.d & n.a & n.a & n.a & n.a & 0 \\
\hline Horton River at Rider (Killara) & 75 & n.d & n.d & n.a & n.a & n.a & n.a & 0 \\
\hline Warialda Creek at Warialda No 3 & 79 & 0.1 & n.d & 0.51 & 7.77 & 1.00 & 0.1 & 0.33 \\
\hline Carole Creek near Garah & 75 & 2.6 & n.d & 0.14 & 7.16 & 1.00 & 0.0 & 1.58 \\
\hline Gwydir River at Brageen Crossing & 97 & 0.4 & n.d & 0.23 & 7.41 & 1.00 & 0.0 & 0.85 \\
\hline Moomin Creek at Iffley & 78 & 1.7 & n.d & 0.55 & 1.73 & 0.97 & 0.1 & 1.88 \\
\hline Mehi River at Bronte & 95 & 0.5 & n.d & 0.21 & 7.37 & 1.00 & 0.0 & 0.95 \\
\hline Moomin Creek at Glendello & 72 & 0.6 & n.d & 1.05 & 7.37 & 0.92 & 0.2 & 1.15 \\
\hline Gwydir River at Alambie Bridge & 77 & 0.1 & n.d & 0.51 & 7.77 & 0.99 & 0.1 & 0.33 \\
\hline Thalaba Creek at Merrywinebone & 95 & 6.0 & n.d & 0.84 & 6.43 & 0.98 & 1.8 & 8.85 \\
\hline
\end{tabular}

Note: n.d signifies measurements determined to be less than the limit of quantitation.

n.a Signifies not applicability of linear regression to the dataset.

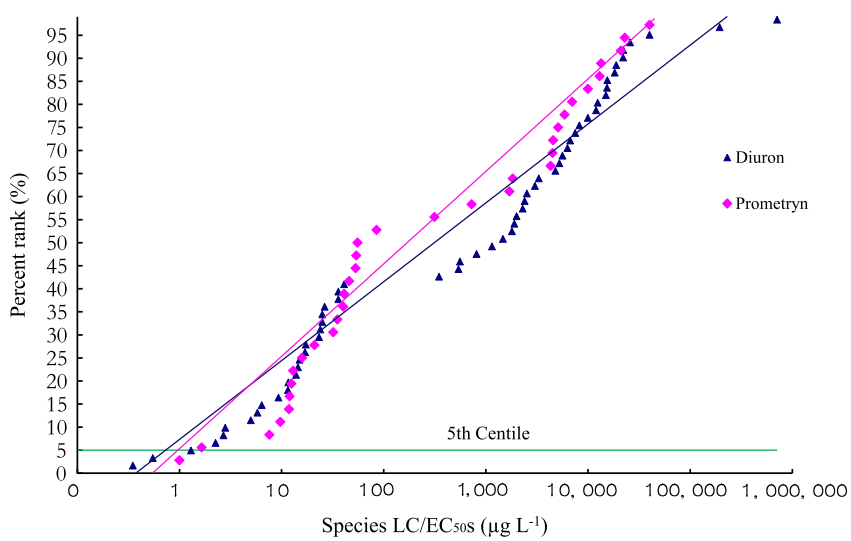

Fig. 3. Distribution of diuron and prometryn toxicity values for aquatic ecosystem.

Creek near Garah, and Thalaba Creek at Merrywinebone) were 4.65 percent, 5.01 percent and 7.27 percent respectively. Risk from exposure to diuron at four sites (Gwydir River at Brageen Crossing, Moomin Creek at Iffley, Mehi River at Bronte, Moomin Creek at
Glendello) was lower, with the exceedence values ranging from 0.36 percent to 2.92 percent. In the other five sites, no risk was apparent. Diuron risk in the Gwydir River catchment is shown in Fig. 4(a).

The 95th centile value in surface water for prometryn in Thalaba Creek at Merrywinebone exceeded the 5th centile of the SSD at 8.85 percent. Risk from exposure to prometryn in all the other sites was very small, with the exceedence values ranging from 0 percent to 1.88 percent. Prometryn risk in the Gwydir River catchment was shown in Fig. 4(b). Comparison of Fig. 4a and b shows that Thalaba Creek at Merrywinebone carried the highest risk for both diuron and prometryn.

\section{Discussion}

By using the 96-well microplate and an ELISA microplate reader, the $\mathrm{EC}_{50}$ values for both diuron and prometryn on the growth of Chlorella were measured. The results were similar to the previous reports on the two herbicides to Chlorella by other assay (Ma et al. 2001, 2002). This bioassay, in which algae was exposed to herbicides 
a

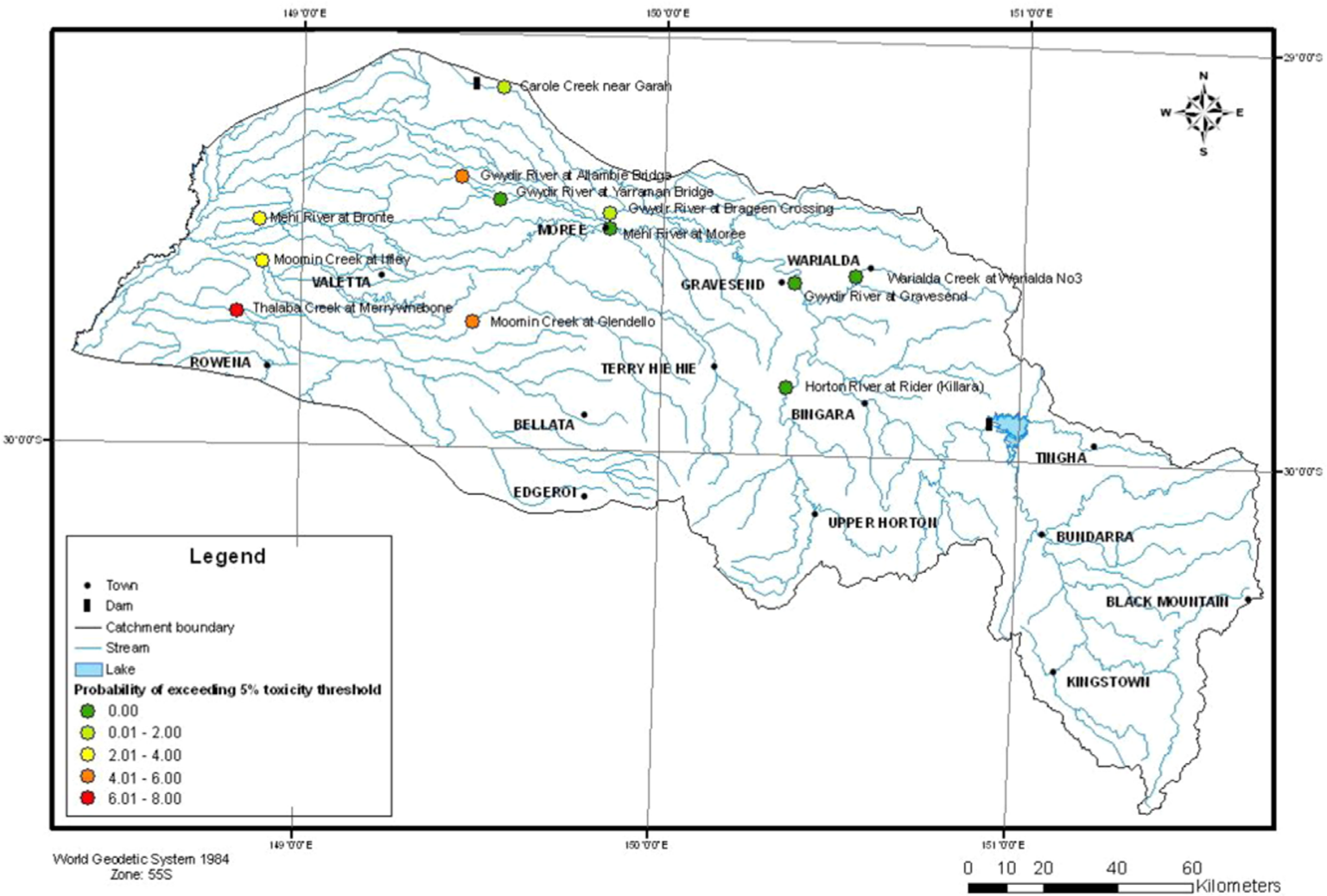

b

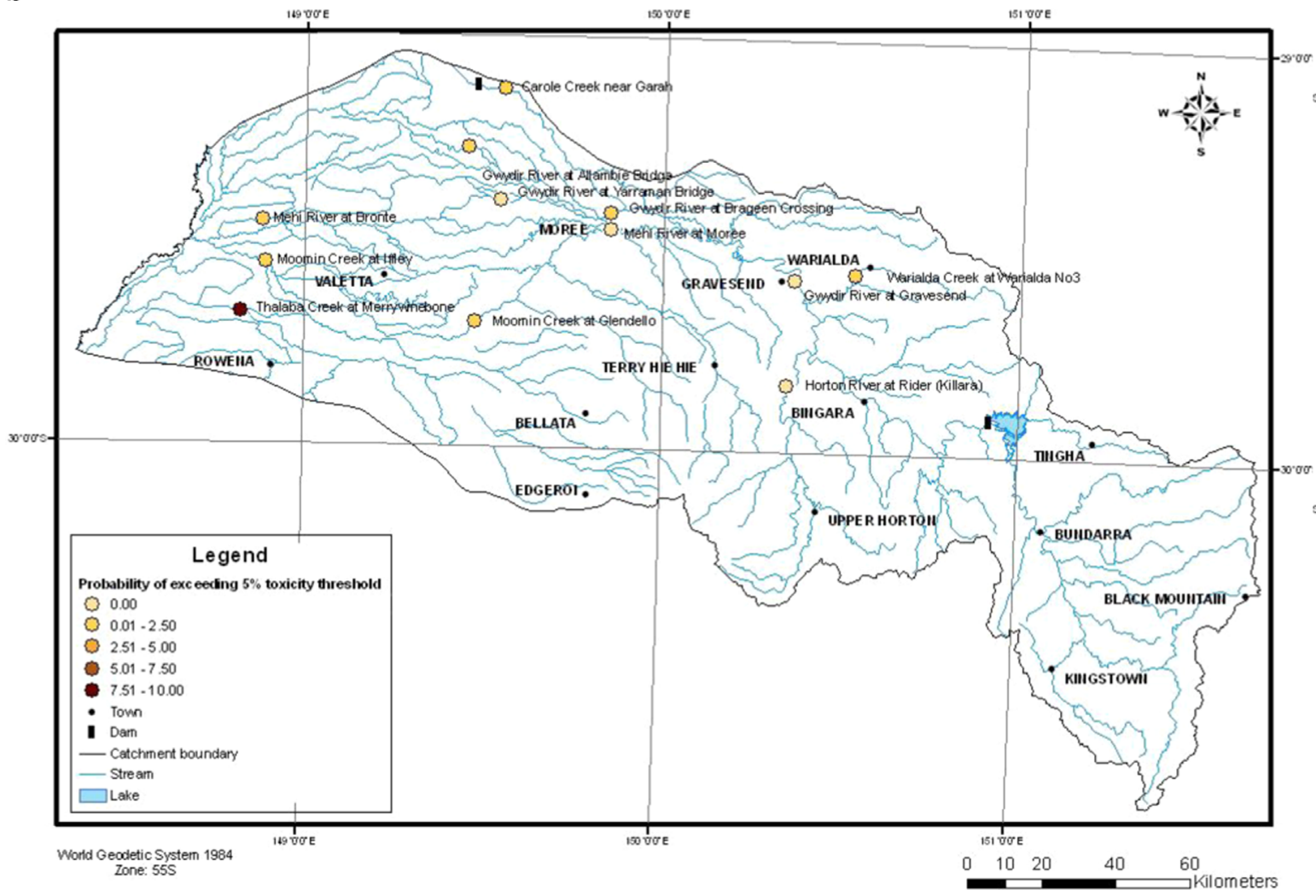

Fig. 4. Map of displaying the level of estimated diuron and prometryn risk at the monitoring sites of the Gwydir River catchment. (a) diuron and (b) prometryn.

by using the 96 -well microplate and their growth was quantified by the measurement of an ELISA microplate reader, saves experimental time, significantly reduces the amount of sample required, handles large number of samples in one experiment, and also improves the repeatability of the results, proves to be a fast and accurate method for evaluating the risk of chemicals on algae. Given the very low 
errors shown in Fig. 2B, a case can be made for adopting this approach as a standardized method.

Both diuron and prometryn inhibit the growth of Chlorella, however, sensitivity to diuron is greater than to prometryn, as shown by the $\mathrm{EC}_{50}$ values. The much lower volatility of diuron (lower $K_{\mathrm{aw}}$ value, appendices Table A) may be part of the reason for its higher rate of toxic effects when compared with prometryn. Other properties of the two herbicides such as water solubility and distribution between water and organic matter are similar, although prometryn is slightly more tightly bound in organic matter than diuron. Diuron also shows more toxicity to other species and even the aqueous ecosystem than prometryn (Fig. 3), confirmed by the SSDs analysis.

$\mathrm{EC}_{50}$ values for both diuron and prometryn are greater than those found in the environment, suggesting that neither of the two herbicides routinely caused irreversible harm to the algae. Some of the assay concentrations (e.g. $10 \mu \mathrm{g} \mathrm{L}^{-1}$ of diuron and $5 \mu \mathrm{g} \mathrm{L}^{-1}$ of prometryn), which are much less than the $\mathrm{EC}_{50}$ and are similar to some environmental concentrations in the study area of the Gwydir catchment, caused inhibition of algal growth, so the likelihood of inhibited growth caused by the low concentrations of these herbicides is sporadic.

Probabilistic risk assessment is a promising approach for evaluating the risk of dangerous chemicals given the availability of toxicity data on local biota and exposure database.

The criteria to select the toxicity data is very important, by which different SSDs can be produced and finally different levels of risk identified. Until now, no standardized criteria are set. Criteria used to select single-species toxicity data were related to test endpoint, duration, effect type, effect measurement and exposure type (Solomon et al., 2000; Solomon and Takacs, 2002; Maltby et al., 2005). The important test endpoints included both the chronic median lethal concentration $\left(\mathrm{LC}_{50}\right)$ and/or median effect concentrations $\left(\mathrm{EC}_{50}\right)$ for aquatic animals and plants (including algae and macrophytes). Lowest observed (LOEC) and no observed (NOEC) effects concentration endpoints were excluded from the SSD because of their lack of statistical rigor, variability at representing effects and low dataset abundance (Laskowski 1995, Kooijman 1996; Posthuma et al., 2002; Suter, 2007). It is recommended that salt and freshwater toxicity data should be combined (De Zwart 2002). The acute toxicology data are the main source of the SSDs. The chronic toxicology data are generally predicted by the acute $\mathrm{EC}_{50}$ with an acute to chronic ratio due to its limited availability. We select the chronic data by keeping longest exposure time instead of extrapolating the values based on the imperial conversion factor.

Where more than one toxicity value was available for a single species, we can select the lowest toxicity value, however it may enlarge the sensitivity. In this study, the geometric mean was calculated to favor the more sensitive studies (Solomon et al., 2000; Maltby et al., 2005).

Thus, by use of probabilistic risk assessment, 'hotspots' for diuron and prometryn risk in Gwydir catchment were identified (Fig. 4a,b); as a result, Thalaba Creek at Merrywinebone was suggested to be the site for the greatest risk of effects of diuron and prometryn. The Gwydir River at Allambie Bridge and Carole Creek near Garah were also diuron risk sites. Management resources would be more effective if resources are targeted to these sites.

\section{Conclusions}

Microplate growth tests are an appropriate method for evaluating the toxicity of herbicides on algae. They could also be adapted for studies on resilience of algal populations subjected to pulsed exposures to pesticides.

Both diuron and prometryn showed concentration dependent toxicity in inhibiting the growth of Chlorella with $\mathrm{EC}_{50}$ of $45 \pm 5$ and $57 \pm 5 \mu \mathrm{g} \mathrm{L}^{-1}$ respectively.

Hotspots for diuron and prometryn risk identified by probability risk assessment in Gwydir catchment suggest that management resources would be most effective if resources are targeted to these sites. The use of microplate assays coupled with probabilistic risk assessment is recommended for rapid assessment of ecotoxicity of indigenous species.

\section{Acknowledgments}

We would like to thank the China National Natural Science Foundation Committee (Project no. 41271487), the Program of International S\&T Cooperation (Grant no. 2012DFA91150), China Scholarship Council, Cotton Catchment Communities CRC, Australia for financial support.

\section{Appendix A. Supporting information}

Supplementary data associated with this article can be found in the online version at http://dx.doi.org/10.1016/j.ecoenv.2014.04.027.

\section{References}

Arensberg, P., Hemmingsen, V.H., Nyholm, N., 1995. A miniscale algal toxicity test Chemosphere 30, 2103-2115.

Bengtson-Nash, S.M., Quayle, P., Schreiber, A.U., Muller, J.F., 2005. The selection of a model microalgal species as biomaterial for a novel aquatic phytotoxicity assay. Aquat. Toxicol. 72, 315-326.

De Zwart, D., 2002. Observed regularities in species sensitivity distributions for aquatic species. In: Posthuma, L., Suter II, G.W., Traas, T.P. (Eds.), Species Sensitivity Distributions in Ecotoxicology. Lewis Publishers, Boca Raton, pp. 133-154.

Eisentraeger, A., Dott, W., Klein, J., Hahn, S., 2003. Comparative studies on algal toxicity testing using fluorometric microplate and Erlenmeyer flask growthinhibition assays. Ecotoxicol. Environ. Saf. 54, 346-354.

Gomez De Barreda Ferraz, D., Sabater, C., Carrasco, J.M., 2004. Effects of propanil tebufenozide and mefenacet on growth of four freshwater species of phytoplankton: a microplate bioassay. Chemosphere 56, 315-320.

Gregor, J., Maralek, B., 2005. A simple in vivo fluorescence method for the selective detection and quantification of freshwater cyanobacteria and eukaryotic algae. Acta Hydrochim. Hydrobiol. 33, 142-148.

Horvatic, J., Peric, V., Pavlic, Z., Stjepanovic, B., Has-Schon, E., 2007. Toxicity of metals on the growth of Raphidocelis subcapitata and Chlorella kessleri using microplate bioassays. Fresenius Environ. Bull. 16, 826-831.

Huang, X., Fong, S., Deanovic, L., Young, T.M., 2005. Toxicity of herbicides in highway runoff. Environ. Toxicol. Chem. 24, 2336-2340.

Jones, R.J., Muller, J., Haynes, D., Schreiber, U., 2003. Effects of herbicides diuron and atrazine on corals of the Great Barrier Reef, Australia. Mar. Ecol. Prog. Ser. 251, 153-167.

Kegley, S.E., Hill, B.R., Orme S., Choi A.H., 2010. PAN Pesticide Database. Pesticide Action Network, North America (San Francisco, CA), 〈http:www.pesticideinfo. org (available at June 20, 2011).

Kellogg, R.L., Nehring, R.F., Grube, A., Goss, D.W., Plotkin, S., 2002. Environmental indicators of pesticide leaching and runoff from farm fields. In: Ball, V.E., Norton, G.W. (Eds.), Agricultural productivity. Springer, US, pp. 213-256.

Kooijman, S., 1996. An alternative for NOEC exists, but the standard model has to be abandoned first. Oikos 75, 310-316.

Laskowski, R., 1995. Some good reasons to ban the use of NOEC, LOEC and related concepts in ecotoxicology. Oikos 73, 140-144.

Ma, J., Xu, L., Wang, S., Zheng, R., Jin, S., Huang, S., Huang, Y., 2002. Toxicity of 40 herbicides to the green alga Chlorella vulgaris. Ecotoxicol. Environ. Saf. 51 (2), 128-132.

Ma, J., Liang, W., Xu, L., Wang, S., Wei, Y., Lu, J., 2001. Acute toxicity of 33 herbicides to the green alga Chlorella pyrenoidosa. Bull. Environ. Contam. Toxicol. 66 (4), 536-541.

Ma, J., Wang, S., Wang, P., Ma, L., Chen, X., Xu, R., 2006. Toxicity assessment of 40 herbicides to the green alga Raphidocelis subcapitata. Ecotoxicol. Environ. Saf. 63, 456-462.

Maltby, L., Blake, N., Brock, T.C.M., Van den Brink, P.J., 2005. Insecticide species sensitivity distributions: importance of test species selection and relevance to aquatic ecosystems. Environ. Toxicol. Chem. 24, 379-388. 
Nguyen-Ngoc, H., Durrieu, C., Tran-Minh, C., 2009. Synchronous-scan fluorescence of algal cells for toxicity assessment of heavy metals and herbicides. Ecotoxicol. Environ. Saf. 72, 316-320.

Nicholls, H.W., 1973. Growth media-freshwater. In: Stein, J.R. (Ed.), Phycological Methods. Cambridge University press, Cambridge7-24.

Orton, F., Lutz, I., Kloas, W., Routledge, E.J., 2009. Endocrine disrupting effects of herbicides and pentachlorophenol: in vitro and in vivo evidence. Environ. Sci. Technol. 43, 2144-2150.

Paixao, S.M., Silva, L., Fernandes, A., O'Rourke, K., Mendonca, E., Picado, A., 2008. Performance of a miniaturized algal bioassay in phytotoxicity screening. Ecotoxicology 17, 165-171.

Posthuma, L., Traas, T.P., de Zwart, D., Suter II, G.W., 2002. Conceptual and technical outlook on species sensitivity distributions. In: Posthuma, L., Suter II, G.W. Traas, T.P. (Eds.), Species Sensitivity Distributions in Ecotoxicology. Lewis publishers, Boca Raton, pp. 475-508.

Rand, G.M., Carriger, J.F., Gardinali, P.R., Castro, J., 2010. Endosulfan and its metabolite, endosulfan sulfate, in freshwater ecosystems of South Florida: probabilistic aquatic ecological risk assessment. Ecotoxicology 19, 879-900.

Relyea, R.A., 2009. A cocktail of contaminants: how mixtures of pesticides at low concentrations affect aquatic communities. Oecologia 159, 363-376.

Riedl, J., Altenburger., R., 2007. Physicochemical substance properties as indicators for unreliable exposure in microplate-based bioassays. Chemosphere 67. $2210-2220$.
Rojiekova, R., Dvofakova, D., Marealek, B., 1998. The use of miniaturized algal bioassays in comparison to the standard flask assay. Environ. Toxicol. Water Qual. 13, 235-241.

Solomon, K.R., Takacs, P., 2002. Probabilistic risk assessment using species sensitivity distributions. In: Posthuma, L., Suter II, G.W., Trass, T.P. (Eds.), Species Sensitivity Distributions in Ecotoxicology. Lewis Publishers, Boca Raton, pp. 285-313.

Solomon, K.R., Baker, D.B., Richards, R.P., Dixon, K.R., Klaine, S.J., La Point, T.W. Kendall, R.J., Weisskopf, C.P., Giddings, J.M., Giesy, J.P., Hall, L.W., Williams, W.M., 1996. Ecological risk assessment of atrazine in North American surface waters. Environ. Toxicol. Chem. 15, 31-76.

Solomon, K., Giesy, J., Jones, P., 2000. Probabilistic risk assessment of agrochemicals in the environment. Crop Prot. 19, 649-655.

Suter II, G.W., 2007. Ecological Risk Assessment, 2nd edition CRC Press, Boca Raton (Fl).

Thellen, C., Blaise, C., Roy, Y. and C. Hickey, 1990. Round Robin testing with the Selenastrum capricornutum microplate toxicity assay. In: Proceedings of the Environmental Bioassay Techniques and their Application Conference, Lancaster, 1988, pp. 259-268.

USEPA, 1998. Guidelines for Ecological Risk Assessment. U.S. Environmental Protection Agency, Washington, DC. 